In addition to Lowi, the Nominating Committee proposed the following slate for Association officers and Council members:

Vice Presidents (1989-90): Robert H. Bates, Duke University; Nannerl Keohane, Wellesley College, Michael Preston, University of Southern California.

Treasurer (1989-91): David Brady, Stanford University.

Secretary (1989-90): M. Crawford Young, University of Wisconsin.

Council (1989-91): Charles Bullock, University of Georgia; Gregory Caldeira, Ohio State University; Catherine Kelleher, University of Maryland; Michael Lipsky, Massachusetts Institute of Technology; Sandy Maisel, Colby College; Judith Stiehm, Florida International University; Ronald Walters, Howard University.

Under APSA's constitution the preceding nominations are subject to the vote of those members of the Association attending the Annual Business Meeting. If there is a contest for any elected office, an election will be conducted by mail ballot. Ballots will be distributed within 30 days of the Annual Business Meeting by the executive director. They must be returned within 30 days following distribution.

The 1989 Annual Business Meeting rules are printed in the Gazette section of this issue of PS. The rules require that any nominations in addition to those made by the Nominating Committee must be received in writing at the Association's Washington office prior to Monday, August 28, 1989, or thereafter at the Association's annual meeting office in the hotel headquarters. All such nominations and certifications must be received at least 24 hours before the session of the Annual Business Meeting in order to include those names on the original nominating document. Specific procedures for offering nominations are included in the Annual Business Meeting rules.

Members of the 1989 Nominating Committee are: Bernard C. Cohen (chair), University of Wisconsin; Lucius Barker, Harvard University; Jennifer Hochschild, Princeton University; Herbert Jacob,
Northwestern University; Dale Rogers Marshall, Wellesley College; Glenn Snyder, University of North Carolina.

Continuing Council members from September 1989-September 1990 are: President: Judith N. Shklar, Harvard University; Council: Christopher Achen, University of Chicago; Kathleen Frankovic, CBS News, New York City; Peter A. Gourevitch, University of California, San Diego; Ted Robert Gurr, University of Colorado; Ronald Kahn, Oberlin College; Barbara Nelson, University of Minnesota; Adolph Reed, Jr., Yale University; Donald Searing, University of North Carolina.

\section{APSA Selects 15 Black American Fellows}

Fifteen students have been named APSA Black American Fellows for the 1989-90

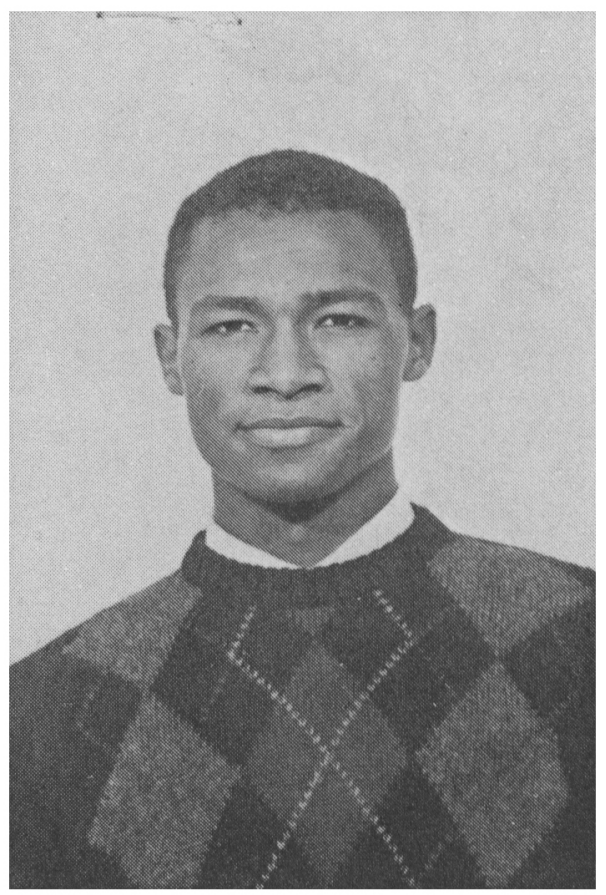

JOAO RESENDE-SANTOS 


\section{Association News}
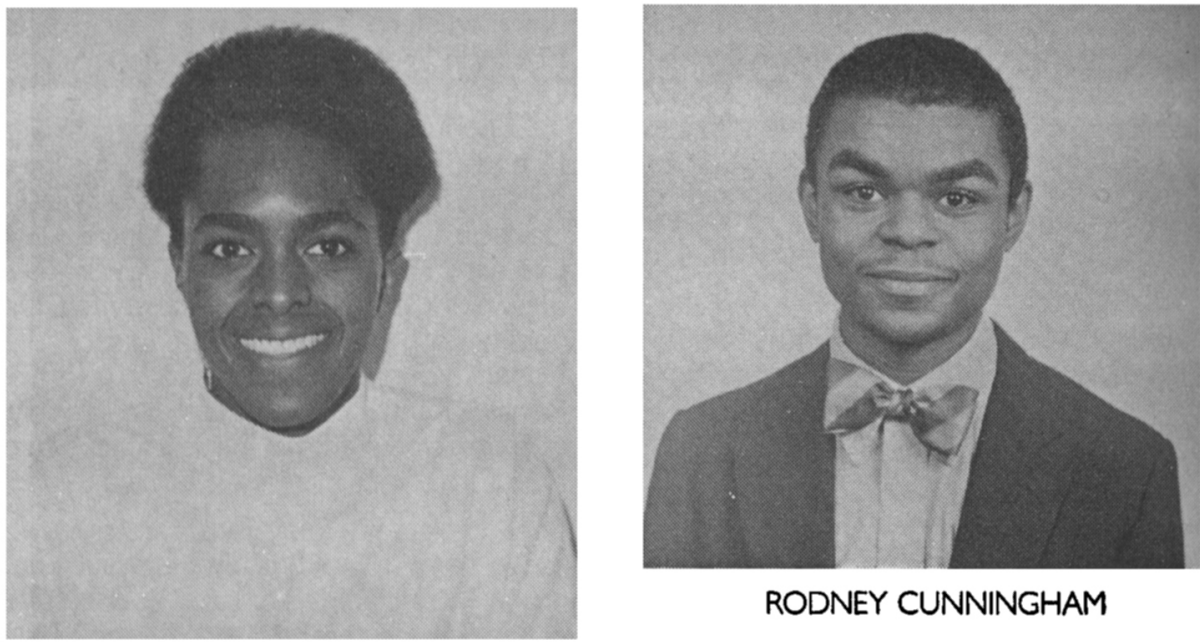

RODNEY CUNNINGHAM

MARC B. VINCENT

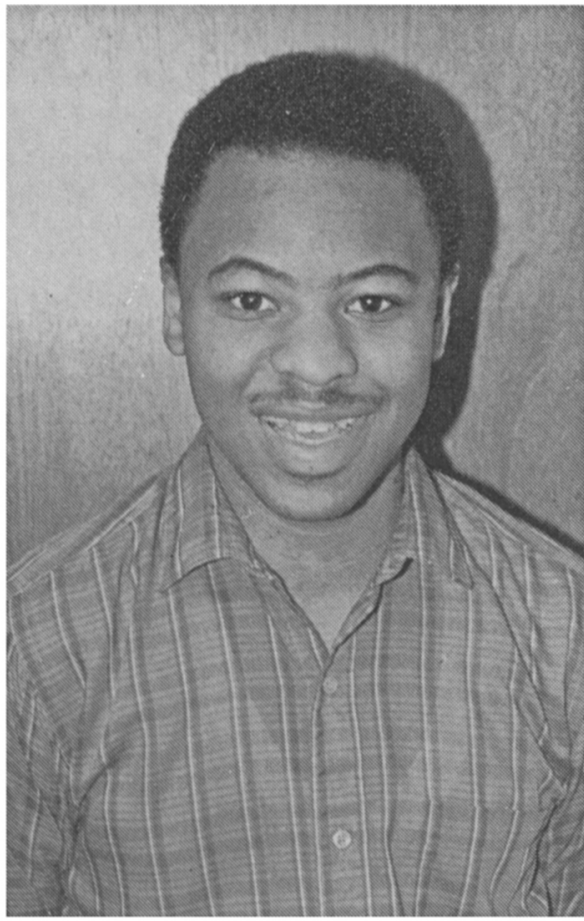

KEVIN ANDERSON

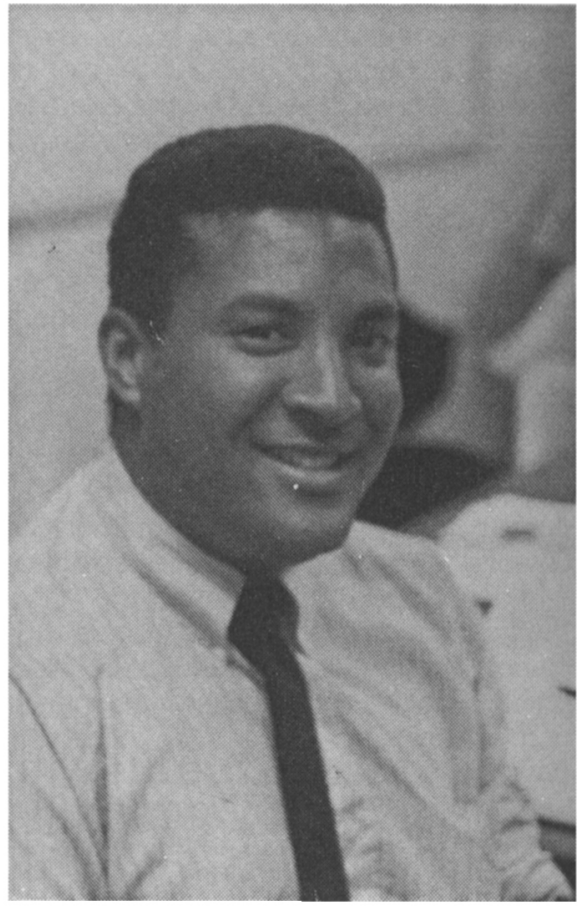

RONALD MILON 


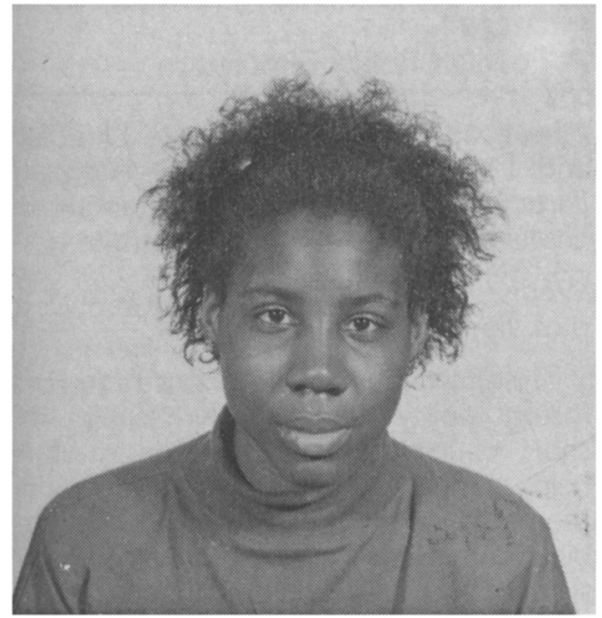

ERISA NDIDI OJIMBA

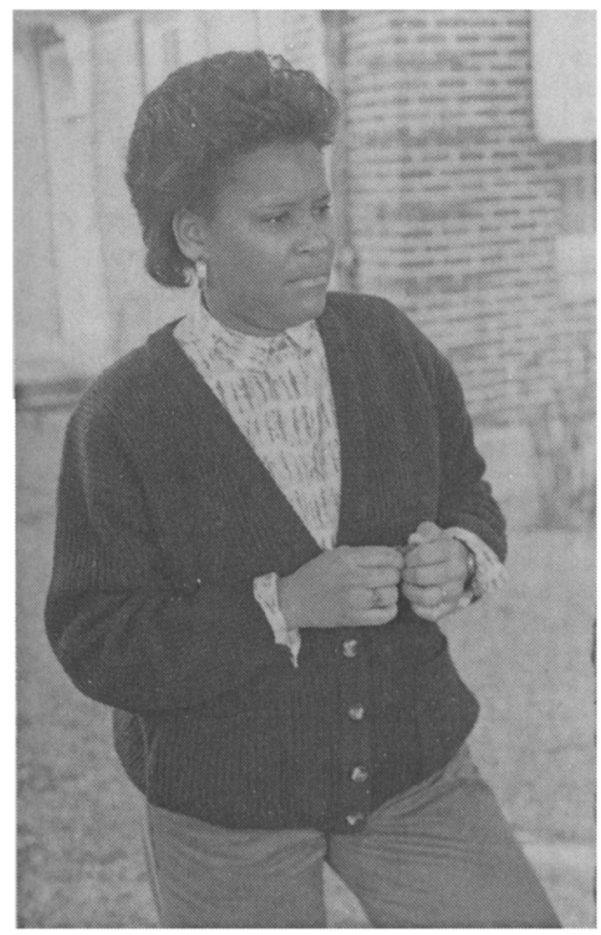

DEBRA F. PARKER academic year. The APSA Black Graduate Fellowship Program is one of the most successful endeavors of the APSA, and it is unmatched by any other social science association. By identifying talented undergraduates interested in pursuing a graduate education in political science, APSA's Committee on the Status of Blacks gives the profession an opportunity to diversity and enrich our discipline.

The 1989-90 Black American Fellows are:

\section{Fellows with Stipend:}

Joao Resende-Santos, Carleton College Heather Sampson, University of Chicago Marc B. Vincent, Stanford University

\section{Fellows without Stipend:}

Kevin Anderson, University of Arkansas, Little Rock

Christopher Blake, Winthrop College Rodney Cunningham, Syracuse University Silvestre Fontes, Boston College Jennifer James, Occidental College Ronald Milon, University of Buffalo Ndidi Ojimba, University of Michigan Debra Parker, Alcorn State University

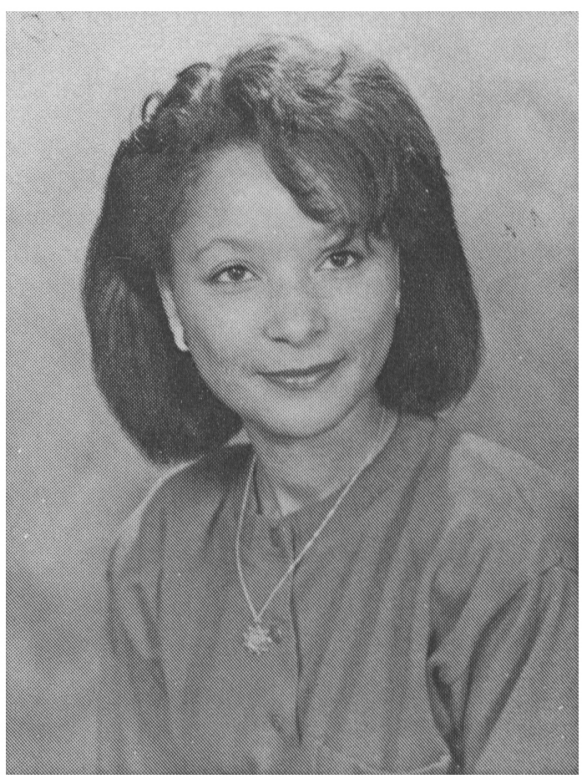

CHERYLYNN RUSH 


\section{Association News}

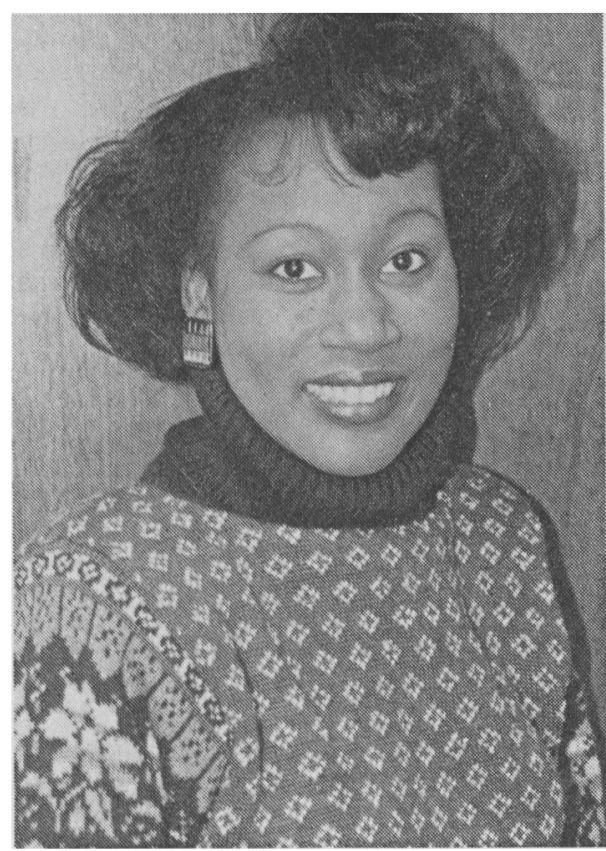

SHERRI WALLACE

Cherylynn Rush, California State University, San Bernardino

Carolyn M. Singleton, Rutgers University

Marsha B. Townsend, University of Maryland, Baltimore

Sherri L. Wallace, University of Arkansas, Little Rock

No Chicano/Latino Graduate Fellows were selected this year. APSA encourages appropriate prospects to apply for this APSA fellowship next year. The deadline is December 1, 1989.

\section{APSA To Offer Short Courses at Annual Meeting}

The Association will offer four intensive short courses on Wednesday, the day before the annual meeting begins, as part of the professional development services offered at the 1989 annual meeting.

The short courses to be offered are:

\section{Hostage Crisis:}

A Foreign Policy Simulation

Moorhead Kennedy, Executive Director, and Martha McDougle Keys, Associate Director, The Council for International Understanding of the Myrin Institute

Wednesday, August 30, 1:30 p.m.-4:30 p.m. Fee: $\$ 25$.

This short course is a demonstration of a foreign policy simulation written by the short course directors and designed to help students think critically, preparing them to cope with complexity and ambiguity in foreign affairs. The plot of the simulation is based on actual hostage incidents, including the Iranian captivity of Moorhead Kennedy. The specific learning objectives of the simulation are to introduce students to:

- the Middle East: Islam, nationalism, economic and social issues,

- the dimensions of international terrorism,

- cross cultural thinking,

- ethical sensitivity,

- survival skills,

- sound decision making and negotiating skills on all levels: personal, national, and international.

The kit for this simulation includes 43 individual role playing booklets, two textbooks, a video and a facilitator's manual.

\section{ICPSR Data Archives: Data Archives: Access and Instructional Uses}

Carolyn Geda and Janet Vavra, ICPSR; William H. Flanigan, University of Minnesota; Charles L. Prysby, University of North Carolina at Greensboro.

Wednesday, August 30, 9:30 a.m.-4 p.m. Fee: $\$ 40$.

This short course focuses on the data archives of the Inter-University Consortium for Political and Social Research and their instructional applications. First, there will be a presentation on data entry and access with a demonstration of access to the system and its reference tools. 